\title{
Simple repair approach for mitral regurgitation in Barlow disease
}

\author{
Sagit Ben Zekry, MD, ${ }^{\mathrm{a}, \mathrm{c}}$ Dan Spiegelstein, MD, ${ }^{\mathrm{b}, \mathrm{c}}$ Leonid Sternik, MD, ${ }^{\mathrm{b}, \mathrm{c}}$ Innon Lev, MD, \\ Alexander Kogan, MD, ${ }^{\mathrm{b}, \mathrm{c}}$ Rafael Kuperstein, MD, ${ }^{\mathrm{a}, \mathrm{c}}$ and Ehud Raanani, MD ${ }^{\mathrm{b}, \mathrm{c}}$
}

\section{ABSTRACT}

Objective: Mitral valve repair for myxomatous Barlow disease is a challenging procedure requiring complex surgery with less than optimal results. The use of ring-only repair has been previously reported but never analyzed or followedup. We investigated this simple valve repair approach for patients with Barlow disease and multisegment involvement causing mainly central jet.

Methods: Of 572 patients who underwent mitral valve repair for mitral regurgitation at our medical center, 24 with Barlow disease (aged $47 \pm 14$ years; 46\% male) underwent ring-only repair. Patients were characterized by severely enlarged mitral valve annulus, multisegment prolapse involving both leaflets, and demonstrated mainly a central wide regurgitant jet. Surgical technique included only the implantation of a large mitral annuloplasty ring. Early and late outcome results were compared with those of the remaining patients who underwent conventional mitral valve repair for degenerative disease (controls).

Results: All ring-only patients presented with moderate-severe/severe mitral regurgitation (vena contracta, $0.6 \pm 0.1 \mathrm{~cm}$; regurgitation volume, $52 \pm 17 \mathrm{~mL}$ ), with mainly a central jet and almost preserved ejection fraction $(59 \% \pm 6 \%)$. Cardiopulmonary bypass and crossclamp times were significantly shorter compared with controls $(P<.0001)$. At follow-up (ring-only, $38 \pm 36$ months and controls, $36 \pm 29$ months), there were no late deaths in the ring-only group compared with $19(4 \%)$ in the controls. Late follow-up revealed New York Heart Association functional class I or II in 95\% of ring-only patients, compared with $90 \%$ of controls. Freedom from recurrent moderate or severe mitral regurgitation was $100 \%$ and $89 \%$ in the ring-only and control groups, respectively.

Conclusions: Mitral annuloplasty for Barlow disease patients with multisegment involvement and mainly central regurgitant jet is both simple and reproducible with excellent late outcomes. (J Thorac Cardiovasc Surg 2015;150:1071-7)

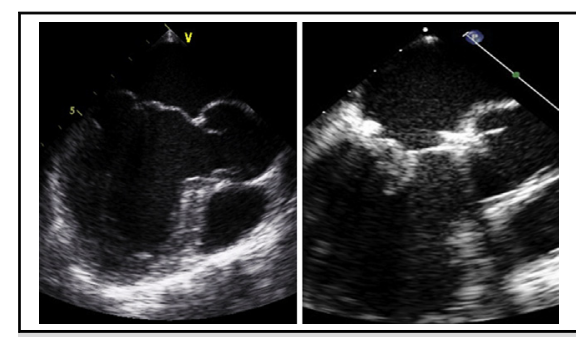

Transesophageal echocardiography. A-D, Before valve repair. $E$ and $F$, After valve repair.

\section{Central Message}

A simple valve repair technique limited to mitral annuloplasty for patients with Barlow disease and multisegment involvement.

\section{Perspective Statement}

Mitral valve repair for myxomatous Barlow disease is a challenging procedure. We present a simple valve repair technique limited to mitral annuloplasty. This technique was applied on 24 patients with Barlow disease and multisegment involvement causing mainly central jet. The technique was found to be reproducible with excellent late outcomes.

See Editorial Commentary page 1078.

\section{Supplemental material is available online.}

\footnotetext{
From the ${ }^{\mathrm{a}}$ Non-Invasive Cardiology Unit and ${ }^{\mathrm{b}}$ Cardiac Surgery Department, Leviev Heart Center, Sheba Medical Center, Tel Hashomer, Israel; and ${ }^{\mathrm{c}}$ Sackler School of Medicine, Tel Aviv University, Tel Aviv, Israel.

S.B.Z. and D.S. contributed equally to this work.

Received for publication May 30, 2015; revisions received July 27, 2015; accepted for publication Aug 9, 2015; available ahead of print Sept 15, 2015.

Address for reprints: Ehud Raanani, MD, Cardiac Surgery Department, Leviev Heart Institute, Sheba Medical Center, Tel Hashomer, Israel 52621 (E-mail: Ehud. Raanani@sheba.health.gov.il).

$0022-5223 / \$ 36.00$

Copyright (c) 2015 by The American Association for Thoracic Surgery

http://dx.doi.org/10.1016/j.jtcvs.2015.08.023
}

Degenerative mitral regurgitation (MR) is the most frequent etiology for severe MR, accounting for most mitral valve (MV) repair surgery. Based on surgical technique advancement and improved surgical outcomes, the American College of Cardiology/American Heart Association guidelines for valvular heart disease recommend MV repair rather than replacement, specifying a class IIa indication for high probability of repair. ${ }^{1}$ Barlow disease, which accounts for up to $30 \%$ of patients who undergo MV repair surgery, ${ }^{2}$ is actually a spectrum of phenotypes with its extreme form manifesting typically in young patients. It is characterized by massive annular dilation, excess thickened leaflet tissue, with a multisegment prolapse, as well as elongated and weak chordae that may often cause flail leaflet. ${ }^{2}$ Repairing this complex form of Barlow pathology is 


$$
\begin{aligned}
& \text { Abbreviations and Acronyms } \\
& \text { MR }=\text { mitral regurgitation } \\
& \text { MV }=\text { mitral valve } \\
& \text { SAM }=\text { systolic anterior motion } \\
& \text { TEE }=\text { transesophageal echocardiography }
\end{aligned}
$$

particularly challenging, with several reports demonstrating reduced reparability with higher MR recurrence and reoperation rates compared with noncomplex degenerative MR repair. $^{3-5}$ In these cases, standard surgical techniques involved extensive leaflet resection, leaflet folding, multiple artificial chordae implantation, and other chordal manipulation techniques, such as chordal shortening and chordal transfer, papillary muscle shortening, and finally complete or incomplete ring placement. ${ }^{2-4,6-10}$ Although repair of Barlow disease has been reported in the literature, specific focus on ring-only repair is lacking, with the exception of Lawrie and colleagues, ${ }^{10}$ who include no detailed discussion on the subject. For example, they fail to describe preoperation valve pathology and long-term echocardiographic follow-up. Thus, we identified a subgroup of Barlow patients in whom the disease involved all of the MV segments where the major jet is central and seen across the entire coaptation line. For this group of patients we used a simple annuloplasty ring-only procedure that we believe provides a very reliable and durable solution to a complex MV pathology. We report the early and late clinical and echocardiography outcomes of this approach. As a control group we compared these outcomes to those of the remaining patients who underwent repair for degenerative MR.

\section{METHODS}

\section{Study Population}

Between 2004 and 2014, 572 patients with degenerative MV regurgitation underwent valve repair at the Cardiac Surgery Department of the Sheba Medical Center. Of them, a subgroup of 24 patients underwent ring-only valve repair. All operations were performed by 2 surgeons (E.R. and L.S.). The study is retrospective using data collected prospectively for all patients.

\section{Baseline Clinical Characteristics}

Compared with the MV repair group, the mitral ring-only patients were characterized by younger age, higher prevalence of women, and lower frequency of hyperlipidemia. Preoperative New York Heart Association functional class, frequency of atrial fibrillation, and/or other risk factors were similar between the groups (Table 1).

\section{Baseline Echocardiogram Characteristics}

Almost normal left ventricular function with enlarged left ventricle end diastolic diameter was noted in both groups (Table 2). As expected, the ring-only group presented myxomatous disease with no flail segment.

\begin{tabular}{|c|c|c|c|}
\hline Parameter & $\begin{array}{c}\text { Ring only } \\
(n=24)\end{array}$ & $\begin{array}{c}\text { Mitral } \\
\text { valve repair } \\
(\mathbf{n}=\mathbf{5 4 8} \text { controls })\end{array}$ & $\begin{array}{c}P \\
\text { value }\end{array}$ \\
\hline Male & $11(46)$ & $432(79)$ & .001 \\
\hline Age $(y)$ & $47 \pm 14$ & $58 \pm 13$ & $<.0001$ \\
\hline $\begin{array}{c}\text { Baseline New York } \\
\text { Heart Association } \\
\text { functional class }\end{array}$ & & & .72 \\
\hline I & $5(23)$ & $170(31)$ & \\
\hline II & $10(45)$ & $241(44)$ & \\
\hline III & $8(32)$ & $132(24)$ & \\
\hline IV & 0 & $5(1)$ & \\
\hline Hypertension & $3(12)$ & $245(45)$ & .001 \\
\hline Diabetes & 0 & $45(8)$ & .25 \\
\hline Hyperlipidemia & $3(12)$ & $200(37)$ & .016 \\
\hline $\begin{array}{l}\text { Chronic obstructive } \\
\text { pulmonary disease }\end{array}$ & 0 & $21(4)$ & 1 \\
\hline Smoking & $2(8)$ & $56(10)$ & 1 \\
\hline Previous stroke & $1(4)$ & $17(3)$ & .54 \\
\hline Chronic atrial fibrillation & $1(4)$ & $63(12)$ & .50 \\
\hline Previous cardiac surgery & 0 & $17(3)$ & 1 \\
\hline
\end{tabular}
Severity of MR was comparable in both groups, although lower pulmonary pressure and smaller left atrium size were seen in the mitral ring-only group (Table 2).
TABLE 1. Patients' clinical characteristics

Values are presented as $\mathrm{n}(\%)$ or mean \pm standard deviation.

Barlow disease was defined in patients presenting with excessive mitral leaflet tissue, billowing valves, and myxomatous degeneration with leaflet prolapse in 1 or both leaflets (overriding of the free edge of the leaflets above the plane of the mitral annulus in systole. $)^{11}$

The 24 patients with Barlow disease had prolapse of multiple segments and massively enlarged annuli (mean annular diameters at the 4-chamber and intracommissure views were $4.4 \pm 0.4 \mathrm{~cm}$ and $4.6 \pm 0.5 \mathrm{~cm}$, respectively). Only patients with major central jet or partially eccentric jet $\left(<45^{\circ}\right.$ to the plane of the MV annulus) were operated on with the ringonly approach. Two patients had a partially eccentric jet $\left(<45^{\circ}\right.$ from the plane of the annulus), whereas all the rest had a dominant central regurgitation jet. Of them, 6 patients had a combined eccentric and dominant central jet. The regurgitation origin was seen right across the coaptation line indicating the involvement of all leaflet segments. When there was a prominent eccentric jet toward the annular plane, other surgical maneuvers were used, and hence these patients were included in the control group. Moderate-severe and severe MR was seen in all patients with a mean regurgitation volume of $53 \pm 17 \mathrm{~mL}$, mean effective regurgitation area of $0.4 \pm 0.3 \mathrm{~cm}^{2}$, and mean vena contracta of $0.6 \pm 0.1 \mathrm{~cm}$.

\section{Surgical Technique}

Intraoperative transesophageal echocardiography (TEE) was performed in all patients to evaluate valvular and ventricular function before and after surgery (Figure 1). All procedures were performed with the use of mild hypothermic cardiopulmonary bypass, and myocardial protection was achieved by intermittent cold blood cardioplegia. Surgical repair was performed by exposing the MV via the traditional left atrial incision parallel to the interatrial sulcus. The incision was started from the superior vena cava and extended inferiorly toward the mitral annulus.

Valve repair included only implantation of annuloplasty rings, with no other repair maneuvers. In the vast majority of patients a complete ring was the ring of choice. When risk of postrepair systolic anterior motion (SAM) was anticipated, a posterior annuloplasty band was used. Intraoperative measuring of the intertrigonal distance was performed and the largest ring possible was implanted. In principle, the largest ring that could adapt to the native MV annulus was chosen. For the closed semirigid rings we 
TABLE 2. Baseline echocardiographic data

\begin{tabular}{|c|c|c|c|}
\hline Parameter & $\begin{array}{l}\text { Ring only } \\
(n=24)\end{array}$ & $\begin{array}{c}\text { Mitral } \\
\text { valve repair } \\
(\mathrm{n}=\mathbf{5 4 8} \text { controls })\end{array}$ & $\begin{array}{c}P \\
\text { value }\end{array}$ \\
\hline $\begin{array}{l}\text { Left ventricular end } \\
\text { diastole diameter }(\mathrm{cm})\end{array}$ & $5.5 \pm 0.5$ & $5.6 \pm 0.7$ & .66 \\
\hline $\begin{array}{l}\text { Left ventricular end } \\
\text { systole diameter }(\mathrm{cm})\end{array}$ & $3.4 \pm 0.6$ & $3.3 \pm 0.6$ & .43 \\
\hline Ejection fraction $(\%)$ & $59 \pm 6$ & $60 \pm 7$ & .31 \\
\hline Myxomatous disease & $24(100)$ & $352(64)$ & $<.0001$ \\
\hline Any mitral valve segment flail & 0 & $360(66)$ & $<.0001$ \\
\hline Mitral regurgitation & & & .26 \\
\hline $\mathrm{I}$ & 0 & 0 & \\
\hline II & 0 & $3(1)$ & \\
\hline III & $7(29)$ & $91(16)$ & \\
\hline IV & $17(71)$ & $454(83)$ & \\
\hline Left atrium area $\left(\mathrm{cm}^{2}\right)$ & $27 \pm 5$ & $31 \pm 9$ & .09 \\
\hline $\begin{array}{l}\text { Estimated pulmonary systolic } \\
\text { pressure }(\mathrm{mm} \mathrm{Hg})\end{array}$ & $33 \pm 8$ & $45 \pm 15$ & $<.0001$ \\
\hline
\end{tabular}

Values are presented as mean \pm standard deviation or $\mathrm{n}(\%)$. purposely oversized on the limit to avoid causing too much tension and subsequent ring dehiscence. Ring types and sizes are shown in Table 3. In the control group, repair techniques included mainly posterior leaflet resection and/or implantation of artificial chordae made of polytetrafluoroethylene (Gore-Tex Sutures; W.L. Gore \& Associates, Inc, Flagstaff, Ariz). Annuloplasty ring implantation was performed in all patients. For both groups, after weaning from cardiopulmonary bypass, the valve repair was evaluated by TEE to confirm successful repair: up to mild MR with good coaptation length (ie, $>7 \mathrm{~mm}$ ), no residual prolapse, and no evidence of SAM (Figure 1).

\section{Clinical and Echocardiographic Data}

Demographic, echocardiographic, and surgical data were collected from our departmental database or from other institutional medical records. Mortality data were retrieved from the official national database, and patients or family members were contacted for clinical follow-up. Followup echocardiography data were obtained from the institutional database, the patients themselves, or ambulatory medical services.

Baseline, intraoperative, and long-term echocardiography data included left ventricular function and dimension, left atrium size, and pulmonary hypertension estimates, all of which were reviewed and documented. Preoperative annulus size and MR severity (ie, vena contracta, effective
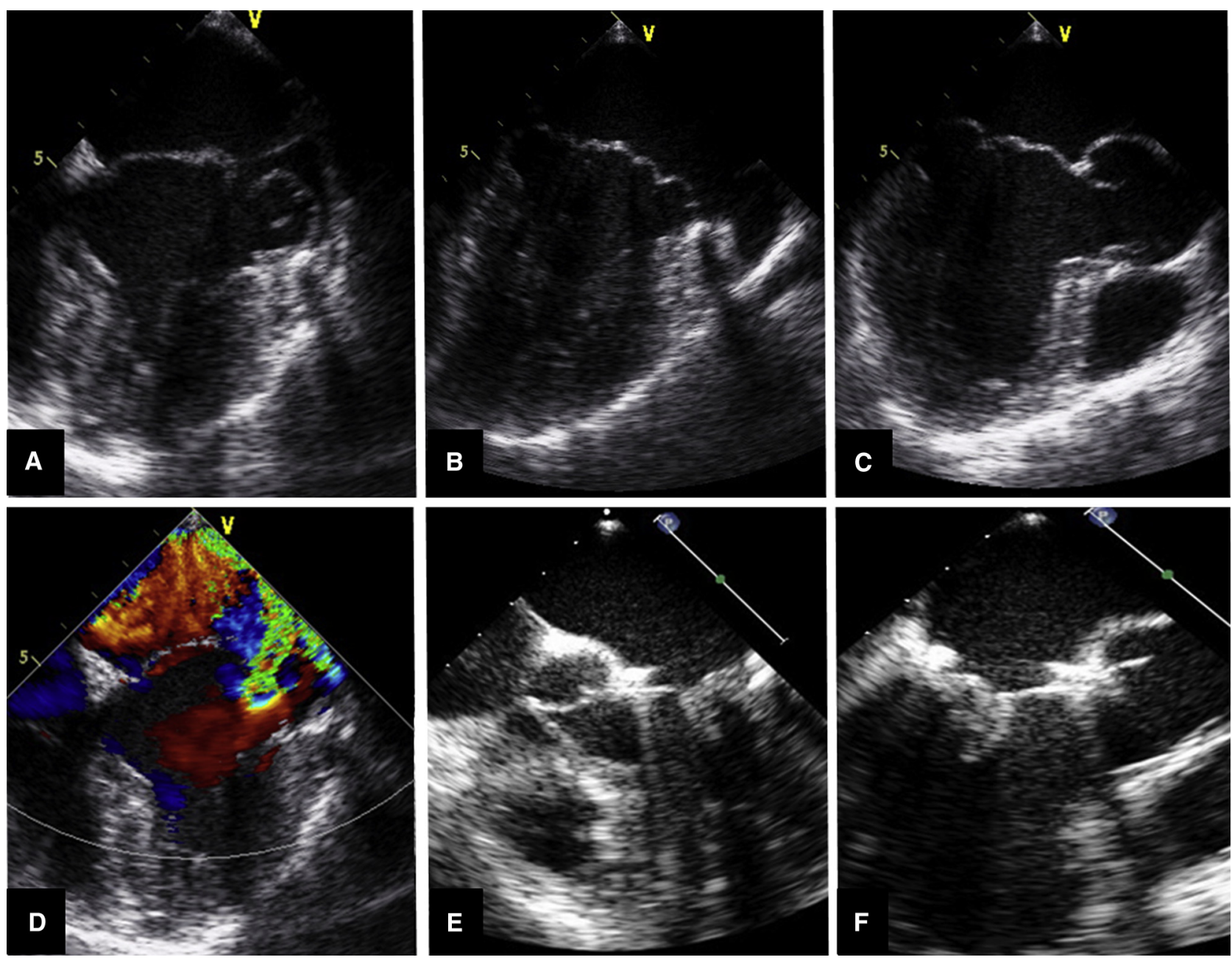

FIGURE 1. Transesophageal echocardiography before and after valve repair. Myxomatous disease with symmetrical involvement of all segments: A, 4-chamber view; B, intracommissure view; C, long-axis view; D, Doppler demonstrating severe mitral regurgitation; E, Postrepair, 5-chamber view with adequate coaptation; and F, long-axis view with no systolic anterior motion. Note leaflet coaptation is below mitral ring level. 
TABLE 3. Operative data and early results

\begin{tabular}{|c|c|c|c|}
\hline Parameter & $\begin{array}{c}\text { Ring only } \\
(n=24)\end{array}$ & $\begin{array}{c}\text { Mitral } \\
\text { valve repair } \\
(\mathbf{n}=\mathbf{5 4 8} \\
\text { controls })\end{array}$ & $\begin{array}{c}P \\
\text { value }\end{array}$ \\
\hline $\begin{array}{l}\text { Cardiopulmonary } \\
\text { bypass time (min) }\end{array}$ & $73 \pm 30$ & $106 \pm 40$ & $<.0001$ \\
\hline Aortic crossclamp time (min) & $54 \pm 20$ & $82 \pm 29$ & $<.0001$ \\
\hline Ring annuloplasty & $24(100)$ & $543(99)$ & 1 \\
\hline Ring size $(\mathrm{mm})$ & $36 \pm 3$ & $35 \pm 3$ & .007 \\
\hline Ring type & & & .17 \\
\hline Carpentier-Edwards Physio* & $20(83)$ & $354(65)$ & \\
\hline Cosgrove-Edwards* & $3(13)$ & $174(32)$ & \\
\hline Carpentier-Edwards Classic* & $1(4)$ & $9(2)$ & \\
\hline Others & 0 & $6(1)$ & \\
\hline Leaflet resection & 0 & $246(45)$ & $<.0001$ \\
\hline Artificial chordae implantation & 0 & $349(64)$ & $<.0001$ \\
\hline $\begin{array}{l}\text { Concomitant coronary } \\
\text { artery bypass grafting }\end{array}$ & $1(4)$ & 75 (14) & .23 \\
\hline Other valvular procedures & $2(8)$ & $97(18)$ & .40 \\
\hline Maze procedures & $3(12)$ & $81(15)$ & 1 \\
\hline Hospitalization stay (d) & $5.2 \pm 1.4$ & $6.4 \pm 4.1$ & .16 \\
\hline Mortality & 0 & $1(0.2)$ & 1 \\
\hline Atrial fibrillation & $5(21)$ & $135(25)$ & .81 \\
\hline $\begin{array}{l}\text { Cerebrovascular } \\
\text { accident/transient } \\
\text { ischemic attack }\end{array}$ & 0 & $14(3)$ & 1 \\
\hline Major bleeding & $5(21)$ & $85(16)$ & .56 \\
\hline Wound infection & 0 & $1(0.2)$ & \\
\hline $\begin{array}{l}\text { Renal failure and/or } \\
\text { need for dialysis }\end{array}$ & 0 & $19(4)$ & 1 \\
\hline
\end{tabular}

regurgitation area, and regurgitation volume) were evaluated. Postrepair coaptation length and across the valve gradients were measured. The presence of SAM was documented. Echocardiographic measurements were taken to demonstrate the geometrical effect of ring-only repair on MV leaflets and the left ventricle (Figure 2). The relationship between the enlarged mitral annulus and the left ventricle apex was ascertained by measuring the angle gamma during end diastole, using transthoracic echocardiography at the 4-chamber view. The maximal mobility of the leaflets was evaluated by measuring the angle between each leaflet and mitral annulus during midsystole, using intraoperative TEE at the 4-chamber view. Beta represents the angle between the posterior leaflet and mitral annulus, whereas alpha represents the angle between the anterior leaflet and mitral annulus. Each angle was measured 3 times and averaged. We repeated the measurements pre- and postrepair.

\section{Statistic Analysis}

All statistical analyses were performed with SPSS software (version 21.0, IBM-SPSS Inc, Armonk, NY). Values are expressed as mean \pm standard deviation or median (interquartile range), as appropriate for continuous variables, and as frequency and percentage for categorical variables. Differences between ring-only and MV repair patients in continuous variables were evaluated by Student $t$ test. Categorical variables were compared using $\chi^{2}$ or Fisher exact test, as appropriate. Differences in preand postsurgery angles (alpha, beta, and gamma) were evaluated by Wilcoxon test.

\section{RESULTS \\ Early Outcomes}

The cardiopulmonary bypass and aortic crossclamp times were significantly shorter for the ring-only group (Table 3 ). Intraoperative TEE confirmed successful repair in all patients with no more than mild MR. In the ring-only group, the postrepair mean coaptation length was $1.2 \pm 0.2 \mathrm{~cm}$. Transient SAM, seen in 7 patients, was abolished in 6 patients, after all patients had received fluid administration and afterload augmentation. Hospital stay and clinical complications were comparable in both groups with no difference in mortality or morbidity (Table 3 ).

\section{Late Outcomes}

Clinical. A mean follow-up period of $38 \pm 36$ months (range, 1-107 months) and $36 \pm 30$ months (range, 1-119 months) was registered for the ring-only group and
Mitral valve Annulus

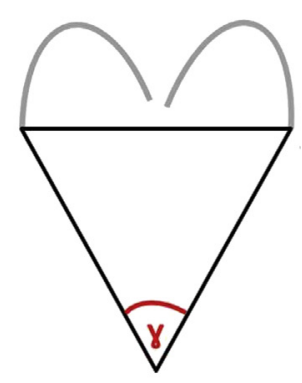

\section{Left Ventricle Apex}

Anterior Leaflet

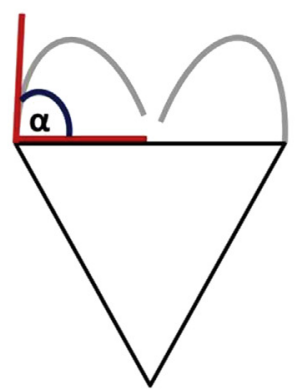

Posterior Leaflet

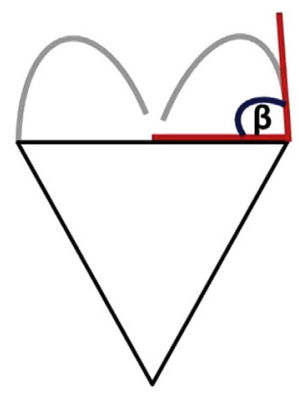

FIGURE 2. Schematic demonstration of mitral valve geometric measurement. The maximal mobility of the leaflets was evaluated by measuring the angle between each leaflet and mitral annulus during mid-systole using transesophageal echocardiography at the 4-chamber view. Beta $(\beta)$ represents the angle between posterior leaflet and mitral annulus, whereas alpha $(\alpha)$ represents the angle between anterior leaflet and mitral annulus. Any angle above the annulus was considered positive and any angle below the annulus was considered negative. The relationship between the enlarged mitral annulus and the left ventricle apex was ascertained by measuring the angle gamma using transthoracic echocardiography at end-diastole. 
TABLE 4. Long-term clinical and echocardiographic results

\begin{tabular}{|c|c|c|c|}
\hline Parameter & $\begin{array}{c}\text { Ring only } \\
(\mathrm{n}=\mathbf{2 4})\end{array}$ & $\begin{array}{c}\text { Mitral } \\
\text { valve repair } \\
(\mathbf{n}=\mathbf{5 4 7} \\
\text { controls })\end{array}$ & $\begin{array}{c}P \\
\text { value }\end{array}$ \\
\hline Clinical follow-up (mo) & & & .72 \\
\hline Average & $38 \pm 36$ & $36 \pm 29$ & \\
\hline Range & $1-107$ & $1-119$ & \\
\hline Late mortality & $0(0)$ & $19(4)$ & 1 \\
\hline $\begin{array}{l}\text { New York Heart Association } \\
\text { functional class }\end{array}$ & & & .65 \\
\hline I & $14(58)$ & $356(65)$ & \\
\hline II & $9(37)$ & $137(25)$ & \\
\hline III & $1(5)$ & $49(9)$ & \\
\hline IV & $0(0)$ & $5(1)$ & \\
\hline Reoperation on mitral valve & 0 & $29(5)$ & .62 \\
\hline Atrial fibrillation & $6(26)$ & $110(20)$ & .59 \\
\hline $\begin{array}{l}\text { Cerebrovascular accident/ } \\
\text { transient ischemic attack }\end{array}$ & $3(13)$ & $47(9)$ & .45 \\
\hline Major bleeding & 0 & $8(2)$ & 1 \\
\hline Echocardiographic follow-up (mo) & & & .21 \\
\hline Average & $36 \pm 20(28)$ & $29 \pm 28(19)$ & \\
\hline Range & $1-98$ & $1-119$ & \\
\hline $\begin{array}{l}\text { Left ventricular end } \\
\text { diastole diameter }(\mathrm{cm})\end{array}$ & $4.8 \pm 0.6$ & $5.0 \pm 0.6$ & 6 \\
\hline $\begin{array}{l}\text { Left ventricular end } \\
\text { systole diameter }(\mathrm{cm})\end{array}$ & $3.2 \pm 0.5$ & $3.2 \pm 0.6$ & .9 \\
\hline $\begin{array}{l}\text { Left ventricular ejection } \\
\text { fraction }(\%)\end{array}$ & $56 \pm 7$ & $56 \pm 7$ & .55 \\
\hline Mitral regurgitation & & & .02 \\
\hline I & $17(70)$ & $208(38)$ & \\
\hline II & $6(26)$ & $279(51)$ & \\
\hline III & $1(4)$ & $49(9)$ & \\
\hline IV & $0(0)$ & $11(2)$ & \\
\hline Mitral peak pressure (mm Hg) & $5.8 \pm 2.3$ & $7.3 \pm 3.6$ & .13 \\
\hline Mitral mean pressure $(\mathrm{mm} \mathrm{Hg})$ & $2.4 \pm 1.4$ & $3.1 \pm 1.6$ & .1 \\
\hline Left atrium area $\left(\mathrm{cm}^{2}\right)$ & $21 \pm 5$ & $24 \pm 8$ & .13 \\
\hline $\begin{array}{l}\text { Estimated pulmonary systolic } \\
\text { pressure }(\mathrm{mm} \mathrm{Hg})\end{array}$ & $27 \pm 7$ & $34 \pm 11$ & .008 \\
\hline
\end{tabular}

Values are presented as mean \pm standard deviation, $\mathrm{n}(\%)$, or mean (median).

controls, respectively $(P=.75)$. Following surgery, most patients in both groups showed significant improvement in their functional capacity, with most classified as New York Heart Association functional class I to II at followup (Table 4). The occurrence of atrial fibrillation and neurologic complications were similar in both groups. Freedom from late mortality was $100 \%$ and $96 \%$ for the ring-only and control group, respectively $(P=1.0)$, and freedom from reoperation was $100 \%$ and $95 \%$, respectively $(P=.63)$ (Table 4).

Echocardiographic evidence. Long-term echocardiography revealed normalization of left ventricle size for both groups, as shown in Table 4. Left atrial size and pulmonary hypertension were reduced. Freedom from MR $\geq 3$ was seen in $100 \%$ of patients in the ring-only group and $89 \%$ in the control group $(P=.02)$.
Mechanism of ring effect. The effect of ring placement on the relationship between mitral annulus and left ventricle apex showed a significant reduction of angle gamma by $13^{\circ}$ (before surgery $33^{\circ}$ [range, $30^{\circ}-35^{\circ}$ ] vs postsurgery $20^{\circ}$ [range, $19^{\circ}-23^{\circ}$ ]; $P=.001$ ) (Figures 2 and 3 ), emphasizing the reduction in left ventricle basal diameter.

Annuloplasty ring implantation caused both leaflets to be pushed down toward the left ventricle apex. Midsystolic posterior leaflet maximal angle was reduced by $85.5^{\circ}\left(62^{\circ}\right.$ [range, $57^{\circ}-76^{\circ}$ ] preoperation to $-23^{\circ}$ [range, $-41^{\circ}$ to $-13^{\circ}$ ] postoperation; $P=.01$ ), whereas the anterior leaflet maximal angle was reduced by $75.5^{\circ}\left(43.5^{\circ}\right.$ [range $36^{\circ}-54^{\circ}$ ] preoperation to $-32^{\circ}$ [range, $43^{\circ}$ to $-5.5^{\circ}$ ] postoperation; $P=.01$ ) (Figures 1 and 3).

\section{Postoperative Transient SAM}

Five of 7 patients in the ring-only group who experienced postoperative transient SAM underwent late stress echocardiography with no evidence of SAM at rest or exercise. ${ }^{12}$ The other 2 patients underwent transthoracic echocardiography that did not demonstrate left ventricular outflow tract obstruction.

\section{DISCUSSION}

The ring-only procedure for degenerative MR has been previously reported but never carefully analyzed or followed-up. ${ }^{10}$ We present the indications, mechanisms of action, and midterm results of this simple surgical approach for patients with Barlow disease with multiple leafletsegment involvement and severely enlarged mitral annulus. These symptoms caused a regurgitation jet right across the coaptation line, which in turn triggered a dominant central regurgitation jet in the majority of cases. We have shown that with this type of pathology, valve repair can be achieved by using an annuloplasty ring only.

In general, MV repair for myxomatous Barlow disease is a challenging procedure, when taking into account multisegment involvement with excess tissue, as well as the enormously enlarged annulus, which together make the repair technically difficult. ${ }^{3-5}$ Repairing myxomatous MV, especially for Barlow disease, requires a complex approach. ${ }^{2,3,-7,10,12-16}$ Most of the earlier reports describe a combination of leaflet resection and annular ring placement with or without chordae insertion. Reviewing the literature, it is difficult to deduce the surgical and echocardiographic results of patients with Barlow disease. Most of the studies do not identify an absolute Barlow group (Table E1). Flameng and colleagues ${ }^{3,5}$ showed a high recurrence rate for MR in Barlow disease, whereas Jouan and colleagues ${ }^{2}$ reported $90 \%$ freedom from recurring MR. Similarly, Lawrie and colleagues ${ }^{10}$ showed a very low $(4 \%)$ recurrence of significant MR, where chordae insertion with annular placement can avert the need for leaflet resection in these patients. 

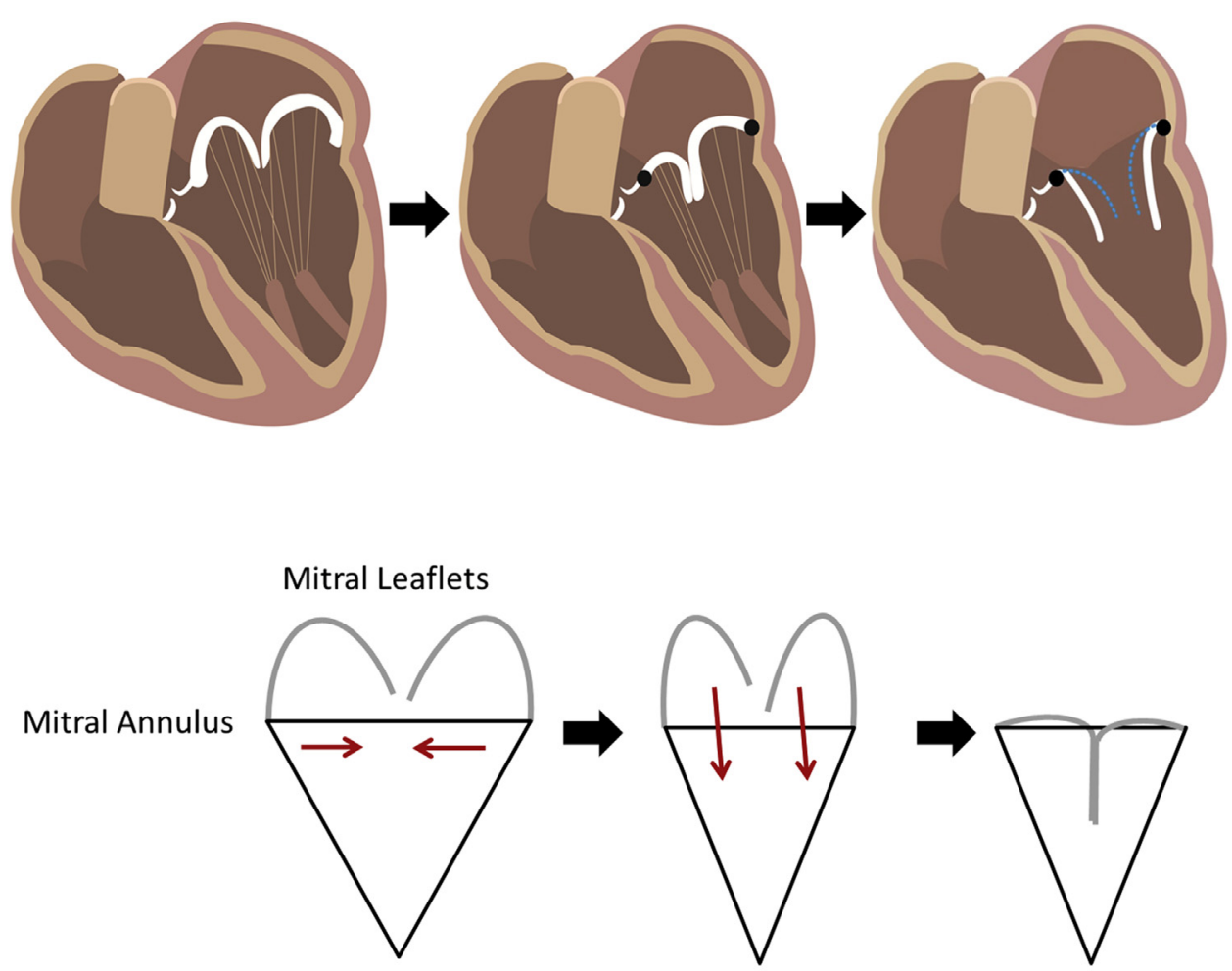

Left Ventricle Apex

FIGURE 3. Schematic presentation of the mitral ring-only repair. Myxomatous disease is characterized by an enlarged annulus and excess leaflet tissue that has prolapsed (upper row). A triangle with an enlarged base can be draw between the mitral annulus and left ventricle apex (lower row). Placement of a ring and reducing annular size reduces the triangular base and thus mitral leaflets are pushed down toward the left ventricle to coapt at the left ventricle level. Note that leaflet dynamicity is preserved at the left ventricle level.

Although their report included 17 of 61 patients who were treated with a flexible ring only, there was no detailed discussion regarding that specific group of patients..$^{10}$ To the best of our knowledge, this is the only report to discuss in detail the clinical and echocardiographic parameters of ring-only MV repair for Barlow disease.

Relatively short bypass and crossclamp times were demonstrated $(82 \pm 29$ minutes and $54 \pm 20$ minutes, respectively) and early outcomes were excellent with no mortality, low morbidity, and short hospital stay. At follow-up, there was no need for reoperation and no significant recurrence of MR or SAM.

\section{Pathophysiology}

Patients with Barlow disease have enormously enlarged annulus size and extremely excessive leaflet tissue (Figure 1, A-D). Placement of a mitral annuloplasty ring remodels the MV shape and reduces annulus size (Figure 3). As the annulus size decreases, leaflets get closure and are pushed down toward the left ventricle apex (Figure 1, E-F). Consequently, the excess leaflet tissue meets to coapt at the level of the ventricle below the mitral annulus, and the prolapse is rarely seen. Subsequently, leaflet mobility is limited to the lower angles toward the mitral annular plane, as demonstrated in Figure 3. This approach results in very long postoperative MV leaflet coaptation length $(1.3 \pm 0.3 \mathrm{~cm})$. Postrepair long coaptation is considered a favorable predictor for long-term durability of the repair, probably because it reduces the stress imposed on the chorda tendinea during systole. However, this approach of using a ring only with no tissue resection bares a couple of serious concerns. First, excessive tissue may cause functional MV stenosis, and second, it heightens the risk of postoperative SAM.

\section{Postoperative MV Stenosis}

The largest possible ring (mean size, $36 \pm 3 \mathrm{~mm}$ ) was used to avoid stenosis. Early and late postoperative echocardiograms showed no evidence of MV stenosis with low diastolic gradients across the valve (peak and mean gradients of $5 \pm 2 \mathrm{~mm} \mathrm{Hg}$ and $2 \pm 1 \mathrm{~mm} \mathrm{Hg}$, respectively). Although excess leaflet tissue remains, its properties, such as flexibility, allow a wide MV opening during diastole, and is therefore capable of avoiding a stenosis effect. 


\section{Postoperative SAM}

SAM of the MV is of considerable concern in cases of repair in Barlow disease, particularly when no tissue is resected. Seven patients experienced postrepair intraoperative transient SAM that was abolished in 6 of them in the operating room using conservative measures. Five of these 6 patients continued to be investigated at late follow-up using rest and stress echocardiography. None of them had evidence of SAM. The absence of SAM could be partly related to the very low apical position of the free edge of the MV leaflets, below the left ventricular outflow tract preventing the venturi phenomena at the left ventricular outflow tract level.

\section{Limitations}

This was a retrospective study with data taken from a single center. The surgical technique was selected in the operating room by the surgeon. This innovative technique was not evaluated against other surgical techniques. It would be difficult to conduct a randomized study to compare MV repair in this highly select group of patients. Because we present a relatively new surgical technique, the wide follow-up period of 1 to 107 months could be a limiting factor.

\section{CONCLUSIONS}

The implantation of mitral annuloplasty only for MV repair in patients with Barlow disease with multisegment involvement who present mainly with a central jet is a safe, simple, and reproducible procedure with excellent late follow-up results.

\section{Conflict of Interest Statement}

Authors have nothing to disclose with regard to commercial support.

The authors thank Dr Hartzell Schaff, Mayo Clinic, who was the first to draw their attention to this surgical option.

\section{References}

1. Nishimura RA, Otto CM, Bonow RO, Carabello BA, Erwin JP III, Guyton RA, et al. 2014 AHA/ACC Guideline for the Management of Patients with Valvular Heart Disease: executive summary: a report of the American College of
Cardiology/American Heart Association Task Force on Practice Guidelines. Circulation. 2014;129:2440-92.

2. Jouan J, Berrebi A, Chauvaud S, Menasche P, Carpentier A, Fabiani JN. Mitral valve reconstruction in Barlow disease: long-term echographic results and implications for surgical management. J Thorac Cardiovasc Surg. 2012;143(4 Suppl): S17-20.

3. Flameng W, Meuris B, Herijgers P, Herregods MC. Durability of mitral valve repair in Barlow disease versus fibroelastic deficiency. J Thorac Cardiovasc Surg. 2008;135:274-82.

4. Melnitchouk SI, Seeburger J, Kaeding AF, Misfeld M, Mohr FW, Borger MA Barlow's mitral valve disease: results of conventional and minimally invasive repair approaches. Ann Cardiothorac Surg. 2013;2:768-73.

5. Flameng W, Herijgers P, Bogaerts K. Recurrence of mitral valve regurgitation after mitral valve repair in degenerative valve disease. Circulation. 2003;107: 1609-13.

6. Newcomb AE, David TE, Lad VS, Bobiarski J, Armstrong S, Maganti M. Mitral valve repair for advanced myxomatous degeneration with posterio displacement of the mitral annulus. J Thorac Cardiovasc Surg. 2008;136: 1503-9.

7. Bellitti R, Petrone G, Buonocore M, Nappi G, Sante P. Anatomic reconstruction in degenerative mitral valve bileaflet prolapse: long-term results. Ann Thorac Surg. 2014;97:563-8.

8. Mihaljevic T, Blackstone EH, Lytle BW. Folding valvuloplasty without leaflet resection: simplified method for mitral valve repair. Ann Thorac Surg. 2006; 82:e46-8.

9. Gazoni LM, Fedoruk LM, Kern JA, Dent JM, Reece TB, Tribble CG, et al. A simplified approach to degenerative disease: triangular resections of the mitral valve. Ann Thorac Surg. 2007;83:1658-64; Discussion 1664-5.

10. Lawrie GM, Earle EA, Earle NR. Nonresectional repair of the barlow mitral valve: importance of dynamic annular evaluation. Ann Thorac Surg. 2009;88: 1191-6.

11. Carpentier A. Degenerative valvular disease. In: Carpentier A, Adams DA, Filsoufi F, eds. Carpentier' reconstructive valve surgery from valve analysis to valve reconstruction. Philadelphia: Saunders Elsevier; 2010:267-8.

12. Kuperstein R, Spiegelstein D, Rotem G, Stein M, Kogan A, Sternik L, et al. Late clinical outcome of transient intraoperative systolic anterior motion post mitral valve repair. J Thorac Cardiovasc Surg. 2015;149:471-6.

13. Chan V, Ruel M, Chaudry S, Lambert S, Mesana TG. Clinical and echocardiographic outcomes after repair of mitral valve bileaflet prolapse due to myxomatous disease. J Thorac Cardiovasc Surg. 2012;143(4 Suppl):S8-11.

14. David TE, Ivanov J, Armstrong S, Christie D, Rakowski H. A comparison of outcomes of mitral valve repair for degenerative disease with posterior, anterior and bileaflet prolapse. J Thorac Cardiovasc Surg. 2005;130:1242-9.

15. Borger MA, Mohr FW. Repair of bileaflet prolapse in Barlow syndrome. Semin Thorac Cardiovasc Surg. 2010;22:174-8.

16. Suri RM, Burkhart HM, Daly RC, Dearani JA, Park SJ, Sundt TM III, et al Robotic mitral valve repair for all prolapse subsets using techniques identical to open valvuloplasty: establishing the benchmark against which percutaneous interventions should be judged. J Thorac Cardiovasc Surg. 2011;142: 970-9.

Key Words: Mitral valve, mitral regurgitation, valve repair 
TABLE E1. Reports of mitral valve repair for Barlow disease

\begin{tabular}{|c|c|c|c|c|c|c|c|}
\hline First author & $\begin{array}{c}\text { Mitral valve } \\
\text { pathology }\end{array}$ & Number & Barlow & Follow-up (y) & $\begin{array}{c}\text { Overall } \\
\text { survival }(\%)\end{array}$ & $\begin{array}{c}\text { Freedom from } \\
\text { late mitral } \\
\text { regurgitation }(\%) \\
\end{array}$ & $\begin{array}{l}\text { Freedom from } \\
\text { reoperation }(\%)\end{array}$ \\
\hline Jouan $^{2}$ & Barlow & 200 & All & 8 & $88.6 \pm 3.1$ & $90.2 \pm 3.1$ & $95.3 \pm 1.7$ \\
\hline Flameng $^{3}$ & Fibroelastic disease & 348 & 83 & 10 & $80.1 \pm 3.7$ & $\begin{array}{l}\quad 64.9 \pm 5.6 \\
\text { Higher recurrence } \\
\text { rate for Barlow }\end{array}$ & $\begin{array}{c}94.4 \pm 1.6 \\
96.6 \text { vs } 86.1 \text { for Barlow }\end{array}$ \\
\hline Flameng $^{5}$ & Degenerative disease & 242 & 45 & 8 & $90.9 \pm 3.2$ & $\begin{array}{l}71.1 \pm 7.4 \text { at } 7 \mathrm{y} \\
\text { More pronounced for } \\
\text { Barlow but not } \\
\text { statistically significant }\end{array}$ & $94.2 \pm 2.3$ \\
\hline Newcomb $^{6}$ & $\begin{array}{l}\text { Advanced myxomatous } \\
\text { degeneration }\end{array}$ & 183 & No data & 10 & $92 \pm 3$ & $80 \pm 5$ & $92.9 \pm 3$ \\
\hline Bellitti $^{7}$ & $\begin{array}{l}\text { Myxomatous } \\
\text { degenerative } \\
\text { Bileaflet prolapse }\end{array}$ & 140 & No data & $6.42 \pm 3.1$ & 95.8 & 78.7 & 91.8 \\
\hline Lariew $^{10}$ & $\begin{array}{l}\text { Myxomatous } \\
\text { degeneration }\end{array}$ & 428 & 61 & $1.2 \pm 2.1$ & & $\begin{array}{l}\text { Freedom from grade } \\
4 \text { mitral regurgitation: } \\
4.2 \% \text { for Barlow } \\
4 \% \text { for non-Barlow } \\
\text { myxomatous valve }\end{array}$ & $\begin{array}{l}1 \text { Patient } \\
\text { underwent } \\
\text { reoperation }\end{array}$ \\
\hline Chan $^{13}$ & $\begin{array}{l}\text { Myxomatous } \\
\text { degenerative } \\
\text { bileaflet prolapse }\end{array}$ & 142 & 42 & 5 & $95.2 \pm 2.8$ & $92.6 \pm 3.9$ & $94.0 \pm 4.9$ \\
\hline David $^{14}$ & Degenerative disease & $\begin{array}{l}359 \text { Postprolapse } \\
92 \text { Anterior prolapse } \\
250 \text { Bileaflet } \\
\text { prolapse }\end{array}$ & No data & 12 & $75 \pm 5$ & $\begin{array}{l}80 \pm 4 \text { For posterior } \\
\text { prolapse } \\
65 \pm 8 \text { For anterior } \\
\text { prolapse } \\
67 \pm 6 \text { For bileaflet } \\
\text { prolapse }\end{array}$ & $\begin{array}{l}96 \pm 2 \text { For posterior } \\
\text { prolapse } \\
88 \pm 4 \text { For anterior } \\
\text { prolapse } \\
94 \pm 2 \text { For bileaflet } \\
\text { prolapse }\end{array}$ \\
\hline Borger $^{15}$ & $\begin{array}{l}\text { Barlow } \\
\text { Bileaflet prolapse }\end{array}$ & 580 & 144 & 10 & No data & No data & 96 \\
\hline Suri $^{16}$ & Mitral valve prolapse & $\begin{array}{l}77 \text { Bileaflet prolapse } \\
103 \text { Posterior leaflet } \\
6 \text { Anterior prolapse }\end{array}$ & No data & $30 \mathrm{~d}$ & $100 \%$ & No data & No data \\
\hline
\end{tabular}

